\title{
SIGNIFICANCE OF THE COMPARABILITY ANALYSIS IN THE TRANSFER PRICING REPORT
}

\section{Jelena Popović Stefanović}

$\mathrm{PhD}$ candidate,

Singidunum University,

Belgrade, Serbia
Correspondence:

Jelena Popović Stefanović

e-mail:

jelena.popovic.stefanovic.17@singimail.rs

\begin{abstract}
:
The subject of the research is a comparability analysis that has to be done in order to completely apply the arm's length principle and to properly do transfer pricing report by any of three methods (standard - transactional - methods, profit methods or other methods). The aim of the study is to underline the significance of a comparability analysis, especially from the aspect of answering numerous questions that arise during the preparation of the transfer pricing report. Some of the relevant answers are: the consistency of the comparability between controlled and uncontrolled transactions, correlation of the result obtained with the company strategy or contractual terms, use of the comparative analysis in the best way to complete transfer pricing report. The main hypothesis, which has been proven through the work, is that part of the comparability analysis (analysis of comparative conditions) can become the method for checking transfer prices.
\end{abstract}

Keywords:

transfer pricing report, comparability analysis, transactions, arm's length principle

\section{INTRODUCTION}

In all countries, tax authorities devote a lot of attention and time to business transactions that take place between related legal entities. The creation of a transfer pricing report is necessary to be attached to the tax balance. This report primarily refers to taxpayers who had transactions with the related legal entities.

If we want to apply arm's length principle and to compare a certain value, price or margin from a transaction with an unrelated legal entity to a transfer price, the transactions we compare (controlled and uncontrolled) are mutually comparable. All factors that may affect the price or profit must be included in the comparability analysis.

According to the Rules on transfer pricing and arm's length principle (2014), when determining the price of transactions between the related legal entities, the most important comparability factors of the application of the method of a comparable price on the market are:

1. The similarity of the transaction subject

2. Contractual terms

3. Economic or market conditions

In our tax practice, two methods (standard methods and methods based on winning) are most commonly used to check the transfer pricing of an enterprise. However, the third method for checking transfer pricing is increasingly present. According to the Corporate Income Tax Law (2001), in addition to these two methods for using the determination of the existence of transfer pricing according to the arm's length principle, the obligor can use any other method based on which it is possible to determine the price of the transaction by using the arm's length principle. 
The aim of the study is to underline the significance of a comparability analysis, especially from the aspect of answering numerous questions that arise during the preparation of the report. In accordance with the above, the subject of the research is a comparability analysis that must be done in order to completely apply the arm's length principle, and for properly done transfer pricing report by any of three methods (standard - transactional - methods, profit methods or other methods). The main hypothesis is that part of the comparability analysis (analysis of comparative conditions) can become the method for checking transfer prices, which has been tested and proven in the work through a practical example accompanied with relevant literature.

In accordance with the defined hypothesis, aim and subject, the research contains five chapters including introduction and conclusion. The next chapter shows relevant literature review for the research; methodology is presented in the third part of the paper, and the results and discussion are presented in the fourth chapter. The conclusion is shown at the end of the paper.

\section{LITERATURE REVIEW}

A comparative analysis of development of transfer pricing reports is well explained and illustrated through a handbook for transfer prices by Negovanovic M. et. al (2015). The same handbook cites generally observed characteristics of particular importance: physical characteristics, quality and reliability, technical and technological characteristics, quality of embedded material, availability, offer... This observation helps us find the characteristics of the product for the comparison in the observed case. Negovanovic et. al (2015) confirmed that functional analysis was primarily important because in the context of the transfer pricing analysis it took responsibility for identifying the economically significant activities and responsibilities that were being undertaken and taken over by businesses in the business relationship, the significant assets they used and the significant risks they were exposed to. This analysis is in fact the process which identifies certain functions that each of the companies from the established business relationship performs.

Since transfer prices are of an international character and relate to all related parties, regardless of where the seat of the parent legal entity is located, and where the seat of the dependent legal entity is, the conclusions of the Informal Meeting on practical transfer pricing issues for developing countries (2011). On the same UN meeting on practical transfer pricing issues for developing countries chapter 7, the relevant information on the industry can be broadly classified in analysis of branch should be:
1. Global economic trends and developments related to the industry to which the enterprise belongs;

2. Economic trends in the taxpayer's resident country for the same industry;

3. Market position of the enterprise and surrounding economic conditions.

Also, according to the UN Meeting on practical transfer pricing issues for developing countries chapter 7 , the important rule is that the return earned by entities involved in a transaction varies directly with the importance of the performed functions, the degree of risk undertaken, and the nature and value of the deployed assets in this way it is explained the complexity of functional analysis, which is applied, as well as what all aspects have to be considered in the functional analysis itself.

This study also relies on the OECD Guidelines for the Implementation of Transfer Pricing Rules for Multinational Enterprises and Tax Administrations (2010), most of the concerns and parts of the Regulation itself derive strength from these guidelines. The full explanation of the shortening of the time, shown through this work, spent on the creation of the transfer pricing report itself lies in transfer pricing rules - Article 2, paragraph 2 (2014), that says that the taxpayer is obliged to show in his transfer pricing report, among other things, well-made functional analysis.

The work relies mostly on the Rulebook on transfer pricing and methods that are arm's length principle (2014) when determining the price of transactions between related parties, primarily because the transfer pricing report is necessary to be attached to the tax balance, and therefore it must be in accordance with regulations and laws.

\section{METHODOLOGY}

In order to successfully carry out a comparative analysis, it is necessary to thoroughly analyze all five factors of the comparative analysis.

The OECD Transfer Pricing Guidelines organization has defined the five comparability factors that are most important in transfer prices in 2010. Those are:

1. The characteristic of the goods or services transferred.

2. The functions performed by the parties (taking into account the assets used and the assumed risks), in relation to the controlled transaction. An examination is often referred to as "functional analysis",

3. The contractual terms of the controlled transaction.

4. The economic circumstances of the parties.

5. The business strategies pursued by the parties in relation to the controlled transaction. 
The method used through the work is the case study method. This method of work is based primarily on regulations, legal regulations, professional scientific papers and thoughts from the relevant field published in the period from 2010 to the present. The entire literature, analysis and conclusions drawn in the paper are linked with a practical example of a company. The company which is in the focus of the analysis is in the field of wholesale of pharmaceutical products Lekovit d. o. o. from Šabac in the further work is labeled Company $\mathrm{L}$. The main sales range of this company consists of medicine, shortage and parafarmation from domestic and foreign suppliers. The company sells its assortment on the territory of the Republic of Serbia. The related legal entity of this company is its buyer, a company that also operates on the territory of the Republic of Serbia in the field of trade in medicines and pharmaceutical products - a pharmacy in further work designated as Company ZU. The analysis was made on the basis of the data obtained from the financial report with opinion of the auditors available on the website of the Business Register Agency of the Republic of Serbia for the observed weekly period of one year, more precisely for the tax year 2016 .

\section{RESULTS AND DISCUSSION}

The first among the factors of comparability to be considered are the characteristics of the goods and services, as it was explained in Negovanovic (2015), that are the subject of the transactions. This factor is particularly important because the differences in goods and services directly reflect the price level in the open market, or in our case. In our case, we will look at (7 drugs in the product group of Company $\mathrm{L}$ that participate in sales revenues with more than 50\%) generic names of drugs and their protected name, dose of the drug and the exact name of the manufacturer, e.g. Bromazepam $3 \mathrm{mg}$, Hemofarm. If the entire group of customers ( 15 of them participating in more than $50 \%$ of the company's turnover) during the entire tax period for which the tax balance is sent out by these seven products, we can consider that the characteristics of the goods and services that are the subject of the transactions are well done and can be used in further analysis.

The obtained results are based on the factors that need to be analyzed in a comparative analysis, explaining each factor and the result obtained by the analysis.

For the analysis of these factors in functional analysis, we will use the following tags (-) - the company does not perform the function, does not hire assets and is not exposed to risk, $\mathrm{x}$ - smaller amount of engaged funds, risk exposure and performance, $\mathrm{xx}$ - moderate amount of assets, risk exposure and performance, $\mathrm{xxx}$ - significant amount of engaged funds, risk exposure and performance.

Table 1 represents analysis of the distribution of functions for Lekovit d. o. o. (Company L) and its related party (ZU Company):

According to the Negovanovic et. al (2015) through the presented functional analysis it was established that the functions that are of great importance and which show the highest level of responsibility for price differentiation for the Company L are quality control, market development, purchase goods, administrative support, the company also has significant material assets and the risks with which they face customer lending risk, risk payment and country risk. What needs to be pointed out is that the related party Company ZU has the same functions and assumes responsibility for the same property and similar risks. Company L applied its functions, assets and risks in transactions with other unrelated legal entities, and that other unrelated legal entities from the same branch as a related legal entity, it can be concluded that it is impossible to differentiate the price only with the related party (Company ZU) based on these functions.

The methods for conducting transactions between related and unrelated legal entities are determined in contracts, where each contractual requirement is precisely defined. What is important to note is that frequent cases where wholesale (as in our case) in their offer have more than 15,000 items, it is unlikely that there are defined terms of sale for each item. In any case, for a good comparability analysis, it is necessary to check each contract of each selected business entity for the analysis. Appendix 1 represents table which cover in the transfer pricing report, for this company, was made for each of the seven mentioned products. Also, from this analysis, it can be seen whether a related legal entity is in a privileged position in relation to other customers of Company L.

Like the functional analysis and the economic circumstances in which the observed companies are located, they must be specifically reflected in the transfer pricing report. For the observed companies in accordance with classification in analysis of branch UN meeting (2011), Appendix (2-4) presents the economic circumstances. Based on the presented analysis of the economic circumstances, we can say that the market in which Company L operates, operates a related party too, but also other independent legal entities, and that there are no differences that can have a significant impact on the price and which concern the economic circumstances.

The observed company identified a strategy of expansion on the market. Since in our case the state prescribes prices, we can conclude that the formation of the price of business strategies applied by the company cannot have an impact on the price of the case, but it has an impact on price differentiation. 
Table 1. Example of functional analysis

Functional analysis

Name of the company

The country in which the observed company is located

Relationship between companies (parent / dependent / associated / joint venture / other type of relationship)

Classification of Entities (Manufacturer, Distributor, etc.)

Description of functions

Manufacturer

Product development

Purchase of goods

Storage

Quality control

Market development

Sales and marketing activities

Post-sales activities

Administrative support

- Determine corporate strategy

- Human resources management

- Information technology

- Finance, accounting and payment transactions

- Law jobs

\begin{tabular}{|c|c|c|c|}
\hline \multirow[t]{3}{*}{$\mathrm{B}$} & Property & $* * *$ & ** \\
\hline & Material & $\operatorname{Not}^{* * *}$ & $\operatorname{Not}^{* *}$ \\
\hline & Intangible & $* * *$ & ** \\
\hline \multirow[t]{12}{*}{$\mathrm{C}$} & Risk analysis & & \\
\hline & Market risk & $* *$ & ** \\
\hline & Risk of stock supply & ** & ** \\
\hline & Costumer lending risk & $* * *$ & ** \\
\hline & Risk of stagnation in stock & ** & ** \\
\hline & Risk of exchange rate & ** & ** \\
\hline & Technological risk & ** & - \\
\hline & Risk of research and development & * & * \\
\hline & Funding risk & * & ** \\
\hline & Risk payment & $* * *$ & * \\
\hline & General risk & ** & ** \\
\hline & Country risk & $* * *$ & $* * *$ \\
\hline
\end{tabular}

Source: Table prepared by author 
By comparing the characteristics of the goods from the analysis, we come to the conclusion that the goods that we used in the analysis are comparable to each other by the fact that all 15 largest customers ordered from Company $\mathrm{L}$ all of the 7 most frequent products from the assortment that were subject of analysis (for example Bromazepam 3mg, Hemofarm was ordered by each of 15 customers from the analysis), so we can go through the next steps of analysis.

Functional analysis has shown that the most important functions of Company L, that influence the price differentiation of used articles, are storage function, marketing control, quality control, etc. While the risks to be highlighted are risk payment and customer lending risk. Also, this functional analysis has been used to complete the transfer pricing report, as a mandatory element of each transfer pricing report, which shortened the time of making transfer pricing report.

The analysis of the contractual conditions showed that the contractual terms for each of the items and for each buyer are mutually comparable, and that the Company L sells goods related to a related party (Company ZU) in approximately the same quantities on the same market and under similar conditions as to other unrelated legal entities for the same goods. In addition, this analysis of the contractual conditions has been used as a method for determining transfer prices within the Other methods an internal comparable price method combined with an externally comparable price. This way we confirmed the main hypothesis and part of a comparative analysis (contractual terms analysis) can become a method for checking transfer prices. This method is also relevant form the point of view of OECD Guidelines Article 2, paragraph 2 (2014).

Although both legal entities (Company L and Company $\mathrm{ZU}$ ) operate on the same market under the same conditions with other competitors and unrelated legal entities, the conclusion of the analysis of economic circumstances for the purpose of comparative analysis is that economic circumstances have no impact on the formation of the price of medicines with Company L, but the prices of all the registered medicines for human use are regulated by the Serbian government, and on the agreed proposal of the Ministry of Health and the Ministry of Trade. In particular, the Law on Medicines and Medical Devices has determined that the government of the Republic of Serbia determines the prices of medicines for human use. In order to realize this competence, the government adopted the Regulation on the criteria for the formation of the price of medicinal products in accordance with this Regulation and the Decision on prices of medicines for human use, which specifies the specific prices for all registered medicines.
Since the Company $L$ is based on the expansion of the existing market (by expanding cooperation with new customers), the conclusion is that the more favorable conditions that occur in transactions with unrelated legal entities are explained by this fact.

Going through these clues, we see that each element of comparative analysis has its own significant place.

\section{CONCLUSION}

The paper emphasizes the significance of the comparability analysis on the example of a large legal entity that is wholesale (Company $\mathrm{L}$ ) and its related retail legal entity or healthcare institution pharmacy (Company ZU). The paper has proven that there is a comparability between the transactions of the observed company (Company L) with its related legal entity (Company ZU) and the unrelated real persons with whom it operates, i.e. that there is a connection between controlled and uncontrolled transactions. Thanks to this action we proceed to further creation of transfer it has been shown through the paper that the Company L strategy does not affect the price of products, but also that the result in terms of the existence of a transfer price is directly related to contractual terms. Of particular importance to the study are two items functional analysis and analysis of economic circumstances. The presented functional analysis for Company L and Company $\mathrm{ZU}$ and the analysis of economic circumstances were used in the transfer pricing report itself as a mandatory part of the report, which significantly shortened the time for the preparation of reports, and then it was determined by functional analysis that functions that influence the differentiation of prices Company L has storage, marketing control and quality control and risks of risk payment and customer lending risk it has been concluded inability to differentiate the price only in favor of the related party, and that economic conditions have no impact on the price in our case.

The main conclusion that has been made is that the main hypothesis is confirmed through the analysis of the contractual conditions itself by the fact that the tax base for Company L is not corrected, that is, the contractual conditions have become the method for checking the transfer prices, which belongs to the group of other methods for determining transfer prices through work.

\section{LITERATURE}

CCIS (2017), Newsletter: Association for Pharmaceutical and Medical Economy, Retrieved September 16, $2018 \mathrm{http}: / /$ www.pks.rs/SADRZAJ/Files/Bilten\%20Farmacija\%2C \%20april\%202017(1).pdf 
Law on Corporate Income Tax Law (2001), Official Gazette of the Republic of Serbia 25/01, 80/02, 80/02 - state law, 43/03, 84/04, 101/11, 119/12, 47/13, 108/13, 68/14 - state law, 142/14, 91/15 - state regulation, 112/15, 113/17

Negovanović M., Čubrić F., Lazović G., (2015), Transfer pricing handbook: Arm's length principle and comparability analysis, Belgrade: Economic adviser; p.p. 87-169

OECD (2010), OECD Transfer pricing guidelines for multinational enterprises and tax administrations, Retrieved September 3, 2018, from http://sfd-ifa.rs/aktivnosti/
Rulebook on transfer pricing and methods that are arm's lengh principle when determining the price of transactions between related parties (2014), Official Gazette of the Republic of Serbia No. 61/13; 8/14

Site of CCIS: http://www.pks.rs/PrivredaSrbije.aspx?id=1804 Retrieved September 16, 2018

United Nations (2011), Financing for development: Working draft on chapter 7, Retrieved September 1, 2018 from http://www.un.org/esa/ffd/tax/2011_TP/

\section{APPENDIX}

Appendix 1. Contractual terms by invoices for medicine Bromazepam tbl 30x30

\begin{tabular}{|c|c|c|c|c|c|c|c|c|c|c|c|}
\hline $\begin{array}{l}\text { Bromazepam } \\
\text { tbl 30x3mg }\end{array}$ & $\begin{array}{c}\text { No } \\
\text { Invoice }\end{array}$ & $\begin{array}{l}\text { Invoice } \\
\text { date }\end{array}$ & $\begin{array}{l}\text { Quan- } \\
\text { tity }\end{array}$ & Price & Rebate & Sum & $\begin{array}{l}\text { Maturity } \\
\text { date }\end{array}$ & $\begin{array}{l}\text { Actually date } \\
\text { of payment }\end{array}$ & Delay & $\begin{array}{l}\% \text { Cash } \\
\text { discount }\end{array}$ & $\begin{array}{l}\text { The way } \\
\text { of distri- } \\
\text { bution }\end{array}$ \\
\hline ZU Related party & 112313 & 23.04 .2016 & 20 & 96 & & 1.920 & 23.05 .2016 & 30.06 .2016 & 37 & $3.00 \%$ & $\begin{array}{c}\text { Lekovits } \\
\text { vehicle }\end{array}$ \\
\hline Customer 1 & 193072 & 16.06 .2016 & 20 & 96 & & 1.920 & 16.07 .2016 & 01.11 .2016 & 76 & $13.00 \%$ & $\begin{array}{c}\text { Lekovits } \\
\text { vehicle }\end{array}$ \\
\hline Customer 2 & 80785-plac & 29.03 .2016 & 8.000 & 96 & 11.6 & 678.912 & 13.04 .2016 & 13.04 .2016 & & & $\begin{array}{c}\text { Lekovits } \\
\text { vehicle }\end{array}$ \\
\hline Customer 3 & 96651 & 12.04 .2016 & 20 & 96 & & 1.920 & 12.05 .2016 & 16.06 .2016 & 30 & $12.00 \%$ & $\begin{array}{l}\text { Lekovits } \\
\text { vehicle }\end{array}$ \\
\hline Customer 4 & 124914 & 25.04 .2016 & 20 & 96 & & 1.920 & 25.04 .2016 & 04.05 .2016 & 9 & $14.00 \%$ & $\begin{array}{c}\text { Lekovits } \\
\text { vehicle }\end{array}$ \\
\hline Customer 5 & 129732 & 26.04 .2016 & 40 & 96 & & 3.840 & 26.05 .2016 & 23.06 .2016 & 28 & $11.00 \%$ & $\begin{array}{c}\text { Lekovits } \\
\text { vehicle }\end{array}$ \\
\hline Customer 6 & 85672 & 01.04 .2016 & 20 & 96 & & 1.920 & 01.05 .2016 & 04.05 .2016 & 3 & $10.00 \%$ & $\begin{array}{l}\text { Lekovits } \\
\text { vehicle }\end{array}$ \\
\hline Customer 7 & 91191 & 07.04 .2016 & 12 & 96 & & 1.152 & 14.04 .2016 & 18.04 .2016 & 4 & $9.00 \%$ & $\begin{array}{c}\text { Lekovits } \\
\text { vehicle }\end{array}$ \\
\hline Customer 8 & 79013 & 28.03 .2016 & 30 & 96 & & 2.880 & 27.04 .2016 & 11.05 .2016 & 14 & $10.00 \%$ & $\begin{array}{c}\text { Lekovits } \\
\text { vehicle }\end{array}$ \\
\hline Customer 9 & 84376 & 31.03 .2016 & 200 & 96 & & 19.200 & 30.04 .2016 & & & & $\begin{array}{l}\text { Lekovits } \\
\text { vehicle }\end{array}$ \\
\hline Customer 10 & 8960 & 15.01 .2016 & 2 & 96 & & 192 & 14.02 .2016 & 23.03 .2016 & 37 & $10.00 \%$ & $\begin{array}{c}\text { Lekovits } \\
\text { vehicle }\end{array}$ \\
\hline Customer 11 & 176255 & 02.06 .2016 & 1.200 & 96 & & 115.200 & 17.06 .2016 & 15.07 .2016 & 31 & $13.00 \%$ & $\begin{array}{l}\text { Lekovits } \\
\text { vehicle }\end{array}$ \\
\hline Customer 12 & 7612 & 13.01 .2016 & 8 & 96 & & 768 & 27.02 .2016 & 01.03 .2016 & 1 & $10.00 \%$ & $\begin{array}{l}\text { Lekovits } \\
\text { vehicle }\end{array}$ \\
\hline Customer 13 & 181557 & 07.06.2016 & 60 & 96 & & 5.760 & 07.07.2016 & 07.07.2016 & & $11.00 \%$ & $\begin{array}{c}\text { Lekovits } \\
\text { vehicle }\end{array}$ \\
\hline Customer 14 & 182921 & 08.06 .2016 & 10 & 96 & & 960 & 07.08.2016 & 08.08 .2016 & & $10.00 \%$ & $\begin{array}{c}\text { Lekovits } \\
\text { vehicle }\end{array}$ \\
\hline
\end{tabular}


Appendix 2. Drug market in Serbia

\begin{tabular}{|c|c|c|c|c|c|}
\hline \multicolumn{6}{|c|}{ Broj pakovanja } \\
\hline & 2012 & 2013 & 2014 & 2015 & 2016 \\
\hline TOTAL MARKET & 243.900 .725 & 250.183 .141 & 245.525 .489 & 268.885 .508 & 274.766 .319 \\
\hline ORIGINATOR Rx & 35.243 .760 & 39.120 .466 & 38.618 .649 & 40.881 .366 & 44.420 .969 \\
\hline GENERIC Rx & 140.489 .064 & 139.071 .669 & 131.485 .836 & 148.114 .184 & 148.347 .263 \\
\hline FS & 27.794 .440 & 29.324 .769 & 31.088 .725 & 34.104 .964 & 36.519 .166 \\
\hline OTC & 40.373 .461 & 42.666 .237 & 44.332 .279 & 45.784 .994 & 45.478 .921 \\
\hline \multicolumn{6}{|c|}{ Finansijski (EUR) } \\
\hline & 2012 & 2013 & 2014 & 2015 & 2016 \\
\hline TOTAL MARKET & 669.167 .659 & 748.290 .614 & 718.182 .547 & 729.139 .587 & 782.443 .462 \\
\hline ORIGINATOR Rx & 250.692 .949 & 286.729 .434 & 279.886 .505 & 277.039 .648 & 303.215 .733 \\
\hline GENERIC Rx & 252.156 .612 & 273.117 .807 & 243.904 .636 & 242.316 .120 & 253.944 .675 \\
\hline FS & 91.023 .147 & 104.565 .859 & 108.515 .450 & 118.613 .135 & 129.917 .897 \\
\hline OTC & 75.294 .951 & 83.877 .514 & 85.875 .956 & 91.170 .684 & 95.365 .158 \\
\hline
\end{tabular}

Source: Chamber of Commerce and industry of Serbia (2012-2016)

Appendix. 3 Sales channels on Serbian market

\begin{tabular}{|c|c|c|c|c|c|}
\hline \multicolumn{6}{|c|}{ Number of packing } \\
\hline & 2012 & 2013 & 2014 & 2015 & 2016 \\
\hline Total & 243.900 .725 & 250.183 .141 & 245.525 .489 & 268.885 .508 & 274.766 .319 \\
\hline Hospitals & 27.893 .934 & 28.297 .153 & 24.951 .222 & 23.803.071 & 22.575 .853 \\
\hline Pharmacies & 216.006 .791 & 221.885 .988 & 220.574 .267 & 245.082 .437 & 252.190 .466 \\
\hline Private pharmacies & 96.488 .679 & 111.521 .651 & 129.061 .937 & 153.661 .944 & 176.230 .355 \\
\hline Public pharmacies & 119.518 .112 & 110.364 .337 & 91.512 .330 & 91.420 .493 & 75.960 .111 \\
\hline \multicolumn{6}{|c|}{ Financial (EUR) } \\
\hline & 2012 & 2013 & 2014 & 2015 & 2016 \\
\hline Total & 669.167 .659 & 748.290 .614 & 718.182 .547 & 729.139 .587 & 782.443 .462 \\
\hline Hospitals & 135.562 .144 & 147.968 .954 & 135.201 .218 & 133.392 .759 & 144.469 .503 \\
\hline Pharmacies & 533.605 .515 & 600.321 .660 & 582.981 .330 & 595.746 .828 & 637.973 .959 \\
\hline Private pharmacies & 220.294 .001 & 277.604 .081 & 320.599 .972 & 367.041 .530 & 437.168 .875 \\
\hline Public pharmacies & 313.311 .514 & 322.717 .579 & 262.381 .358 & 228.705 .298 & 200.805 .084 \\
\hline
\end{tabular}

Source: Chamber of Commerce and industry of Serbia (2012-2016) 


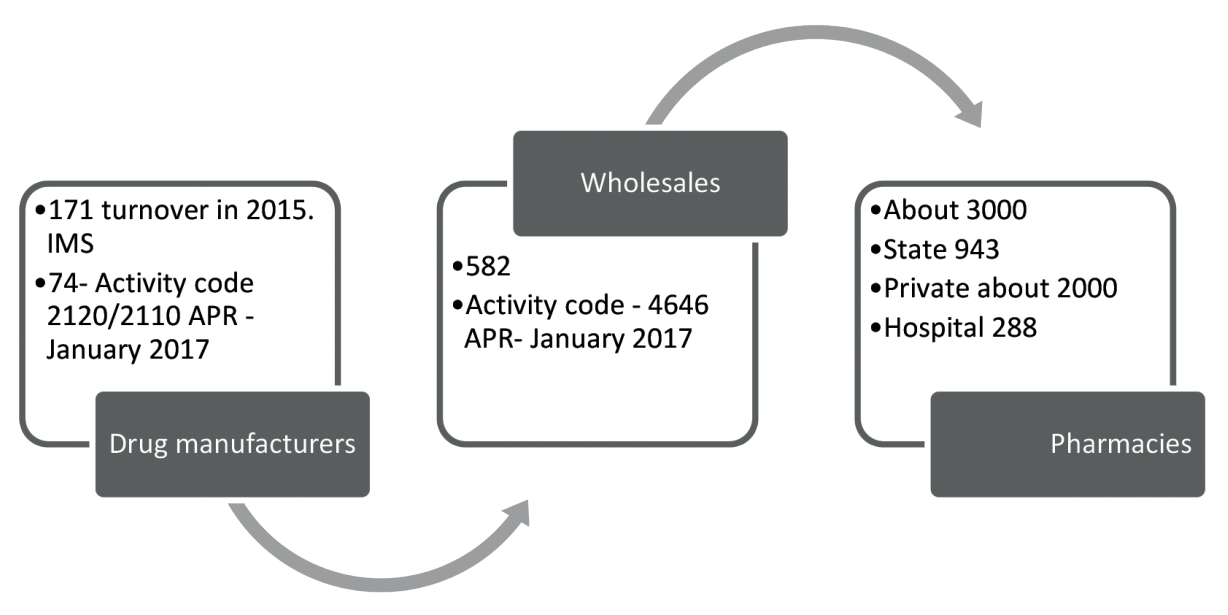

Source: Chamber of Commerce and industry of Serbia (2016) 